\title{
Behavior and seasonal abundance of Neotropic Cormorant Nannopterum brasilianus (Gmelin, 1789) in southeastern, Brazil
}

\author{
Tatiane Lima da Silva ${ }^{1,3}$, Rísia Brígida Gonçalves Cabral ${ }^{1} \&$ Ildemar Ferreira $^{2}$ \\ 1 Programa de Pós-Graduação em Biologia Animal, Instituto de Ciências Biológicas e da Saúde, Universidade Federal Rural do Rio de Janeiro, \\ Rodovia BR 465, km 7, 23897-000, Seropédica, Rio de Janeiro, Brazil. \\ 2 Instituto de Ciências Biológicas e da Saúde, Universidade Federal Rural do Rio de Janeiro, Rodovia BR 465, km 7, 23897-000, Seropédica, Rio \\ de Janeiro, Brazil. \\ 3 Corresponding author: tatianelima@ufrrj.br
}

Received on 18 September 2018. Accepted on 27 November 2018.

\begin{abstract}
The Neotropic Cormorant Nannopterum brasilianus (Gmelin, 1789) is one of the most common and abundant species in Brazil's aquatic environments, but little is known about its natural history. This study elaborates and quantitatively evaluates the ethogram and seasonal abundance of this species at Lake Açu, in Rio de Janeiro, Brazil. Between August 2013 and July 2014, behaviors were registered by the ad libitum sampling method and quantified by the continuous recording during 30-min sessions. The mean number of sighted individuals per month was $30.41 \pm 4.79$. Abundance was higher during the dry season $(41.5 \pm 5.36)$ compared to the rainy season $(19.33 \pm 4.81)(t=3.07, P=0.01)$. A total of 42 behaviors were described and grouped into five behavioral categories: maintenance (83.59\%), ingestion/excretion (10.67\%), locomotion (3.48\%), play (1.65\%), and agonistic behavior $(0.61 \%)$. The time spent in these categories did not vary significantly between the morning and afternoon periods. This study can be used as a starting point for further ethological studies on the species.
\end{abstract}

KEY-WORDS: feeding, Lake Açu, maintenance, Phalacrocoracidae, seasonality.

\section{INTRODUCTION}

The Phalacrocoracidae family includes about 40 species of long-beaked piscivorous waterbirds, with mostly monochromatic plumage and webbed feet, commonly called Cormorants (Kennedy \& Spencer 2014). Despite morphological similarities, the typical behaviors among species in this family may differ according to the inhabited area, due to worldwide distribution (Bernstein \& Maxson 1982). Among different behaviors, wing spreading may be absent or occur only rarely in some Cormorants, in order to avoid loss of heat in cold regions (Cook \& Leblanc 2007).

The Neotropic Cormorant, Nannopterum brasilianus (Gmelin, 1789), the only representative of the family in Brazil, is distributed from the southern United States to southern South America (Sigrist 2009). It presents gregarious habits and inhabits inland waters and seafronts (Sick 1997). The species display brown plumage when young and black when adults, with the presence of white filoplumes on the sides of the head and neck during the reproductive period (Bó 1956). In Brazil, they reproduce in colonies in the Amazon, Pantanal and on islands near the coast of Rio de Janeiro (Sick 1997, Alves et al. 2011).

Although the species is widely distributed and of common occurrence, few studies concerning its natural history have been published. Most include general behavior (e.g., Oliveira \& Costa 2003, Sazima 2008, Branco et al. 2009), distribution patterns (e.g., Alves et al. 2011, Silva et al. 2014) and feeding (e.g., Barquete et al. 2008, Alarcón et al. 2012, Casaux et al. 2012) descriptions.

Ethograms are basic tools used in natural history studies (Sakamoto et al. 2009). They consist of a list of behavioral units and their respective descriptions and can be accompanied by qualitative and quantitative analyses (Yamamoto \& Volpato 2011). Ethograms are reference sources, which may be used in phylogenetic analyses and in the elaboration of hypotheses regarding behavior functionality (Kennedy et al. 1996, Gokula 2011).

Behavior descriptions of $N$. brasilianus are scarce. Previous studies have been described some aspects related to maintenance (Branco et al. 2009), foraging (GhelerCosta et al. 2018), agonistic (Oliveira \& Costa 2003), play (Sazima 2008), feeding associations with piscivorous 
birds (D'Angelo \& Sazima 2013) and dolphins (Santos et al. 2010, Espinoza-Rodríguez et al. 2015), and diving behaviors (Quintana et al. 2004). However, an ethogram has not been produced for the species.

Due to the lack and importance of studies related to natural history, this study elaborates and quantitatively analyses Neotropic Cormorant ethogram and seasonal abundance of the species in an artificial lake in southeastern Brazil. Ethogram was then compared to others previously described for Phalacrocoracidae.

\section{METHODS}

\section{Study area}

This study was performed at the campus of the Universidade Federal Rural do Rio de Janeiro (22046'9.56"S; 4341'13.12"W) in Seropédica, located in the Baixada Fluminense district. The campus comprises 3024 ha (Chiquieri et al. 1995), covering countryside, grazing areas, Atlantic Forest fragments, spontaneous wetlands, and four lakes, three artificial and a natural one (Ferreira et al. 2010). The climate is classified as "Cw" by Koppen's International System, as humid subtropical with a dry season in winter (Alvares et al. 2013).

Observations were carried out on an artificial lake, Lake Açu, located near the Agronomy Institute. The lake comprises an area of $98,538.08 \mathrm{~m}^{2}$ with a depth of 1.75 $\mathrm{m}$. The surrounding vegetation is composed of grasses and sparse trees, including Ziziphus joazeiro, Syzygium cumini and S. malaccense; and palms (Arecaceae), including Caesalpinia echinata, Ficus sp., Mangifera indica, and Psidium guajava.

\section{Field procedures}

Observations were carried out between August 2013 and July 2014. Sixty field trips were performed, totaling $168 \mathrm{~h}$ of sampling effort, where $100 \mathrm{~h}$ comprised the quantitative analyses. Behavioral units were registered by the ad libitum sampling method and quantified by the continuous recording (Altmann 1974). The observed behaviors were photographed, filmed and recorded using spreadsheets. A focal individual was chosen randomly by chance in each session. Therefore the same individual could or could not be chosen in the next session. During each 30-min session, the duration of each individual behavior was counted in minutes. At the end of each session, 10-min intervals were taken, followed by a new session. A total of 100 sessions were sampled in the morning (06:30 $\mathrm{h}$ to $11: 59 \mathrm{~h}$ ) and 100 in the afternoon $(12: 00 \mathrm{~h}$ to $18: 00 \mathrm{~h})$. The division and nomenclature of each behavior were based on the studies carried out by Schleidt et al. (1984), Prestes (2000) and Oliveira \& Costa (2003). Individuals were classified as young if plumage was brown and as adults if plumage was black. Adults with white filoplumes on the sides of the head and neck displayed breeding plumage. The highest number of individuals observed per month was adopted as a measure of monthly abundance.

\section{Statistical analyses}

Data normality (Shapiro-Wilk's test) and homogeneity of variances (Levene's test) were first tested. The difference between the number of individuals sighted during the dry (April to September) and rainy (October to March) seasons was analyzed by Student's $t$-test. The behavioral categories were evaluated regarding differences in duration between morning and afternoon periods by the Student's $t$-test after log-transformation. All tests were performed using the PAST software v. 3.12 (Hammer et al. 2001), adopting a $5 \%$ significance level. Data are presented as means \pm standard error.

\section{RESULTS}

The monthly average of Neotropic Cormorants at Lake Açu was $30.41 \pm 4.79$ individuals, reaching higher and lower values in June 2014 and December 2013, respectively (Fig. 1). Abundances differed between seasons $(t=3.07, P=0.01)$, higher in the dry season $(41.5 \pm$ 5.36) compared to the rainy season $(19.33 \pm 4.81)$. The population was composed by young individuals, except for a record of three adults in reproductive plumage in November 2013.

Forty-two behaviors were identified and described, grouped into five behavioral categories: maintenance (83.59\%), ingestion/excretion (10.67\%), locomotion

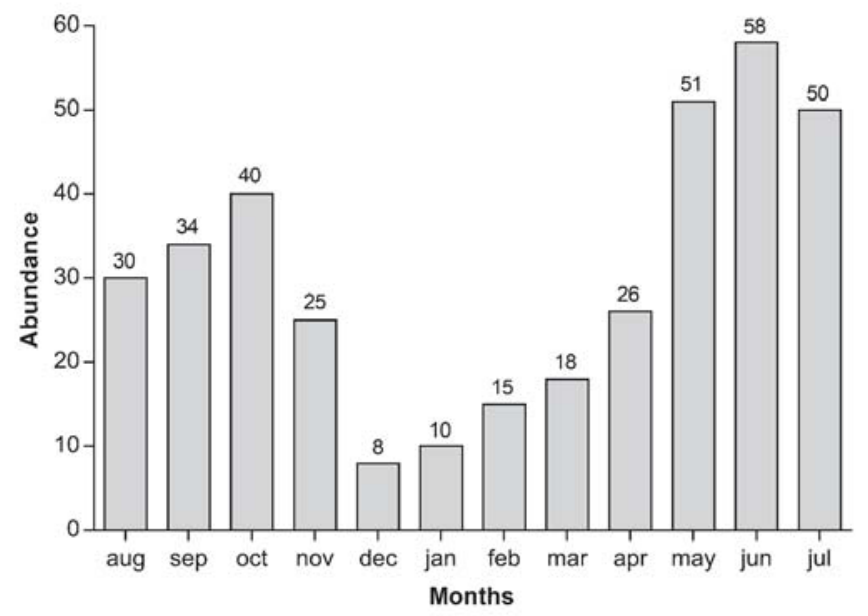

Figure 1. Abundance (highest monthly value) of Nannopterum brasilianus from August 2013 to July 2014 in the Lake Açu, southeastern Brazil. 
(3.48\%), play (1.65\%) and agonistic behavior $(0.61 \%)$ (Fig. 2). These categories did not vary significantly between the morning and afternoon periods (maintenance: $t=$ $-0.21, P=0.83$; ingestion/excretion: $t=-0.02, P=0.98$; locomotion: $t=-0.85, P=0.41$; play: $t=-1.09, P=0.34$; and agonistic behavior: $t=-1.17, P=0.27$ ).

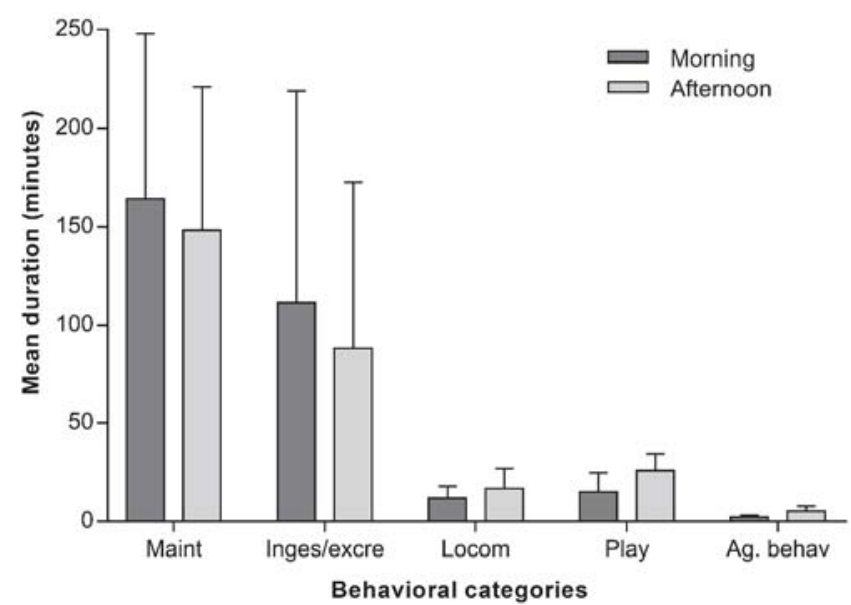

Figure 2. Mean duration and standard error of behavioral categories during the morning $(06: 30 \mathrm{~h}$ to $11: 59 \mathrm{~h})$ and afternoon (12:00 h to 18:00 h) periods (in minutes). Maint - Maintenance, Inges/excre - Ingestion/excretion, Locom Locomotion, Play, and Ag. behav - Agonistic behavior.

\section{Maintenance}

These include behaviors related to resting, body care and plumage activities (Fig. 3).

Head scratching: the bird tilts its head to its chest and lifts one leg toward it. It then moves the tarsi quickly against the head, in top-to-bottom movements. These movements may also be directed to the chin and throat (Fig. 3A).

Back head scratching: the bird moves its neck towards its back, swinging the head against it in quick lateral movements (Fig. 3B).

Tarsus scratching: the bird lifts its leg up close to the abdomen and tilts its head towards the tarsi, with rapid half-open beak movements on the tarsi (Fig. 3C).

Preening: with its wings half-open and low, the bird moves its half-open beak toward the base of the feathers, aligning them, carrying out this movement for feathers throughout the whole body, tilting its head to the region where the feathers will be aligned (Fig. 3D).

Plumage shaking: the bird, with its body leaning forward after exiting the water, shakes its whole body in one quick movement, causing excess water to leave the feathers. This can be followed or preceded by wing, head and tail shaking (Fig. 3E).
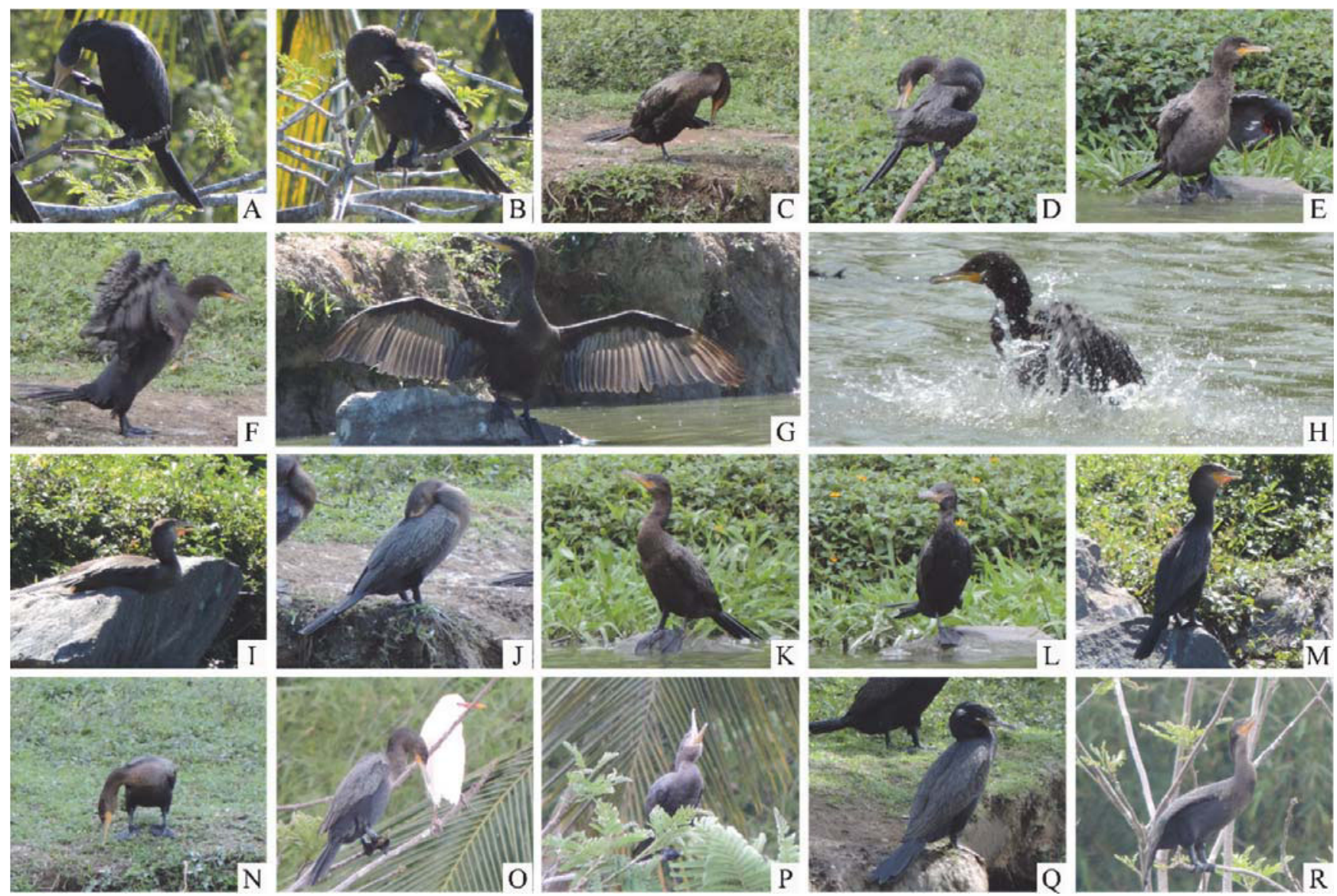

Figure 3. Behavioral conducts of Nannopterum brasilianus in the maintenance category: (A) Head scratching, (B) Back head scratching, (C) Tarsus scratching, (D) Preening, (E) Plumage shaking, (F) Wing shaking, (G) Wing spreading, (H) Bathing, (I) Sitting resting, (J) Back head resting, (K) Bipedal resting, (L) Unipedal resting, (M) Gular-fluttering, (N) Neck lowering, (O) Head lowering, (P) Beak opening, (Q) Neck shrinking (adult with breeding plumage), (R) Wing leg stretching. 
Wing shaking: after leaving the water, the bird tilts its body forward, opens its wings and shakes them in fast and beating movements. Variation: slow wing beating (Fig. 3F).

Head shaking: after leaving the water, the bird swings its head sideways, slow at first, increasing frequency until slowing down again. This also occurs during foraging, after the bird takes its head out of the water.

Tail shaking: after leaving the water, the bird leans its body forward and swings its tail horizontally in short and fast movements.

Wing spreading: after leaving the water, the bird opens its wings horizontally and keeps them still (Fig. $3 \mathrm{G})$.

Bathing: during movement in the water after foraging, the bird leans its body forward and flaps its wings against the water, raising its body from the surface. This may be followed by diving. The bird alternates between displacement in water, dipping, and bathing (Fig. $3 \mathrm{H}$ ).

Sitting resting: the bird remains with its body lowered over its legs, with the abdomen in contact with the substrate (Fig. 3I).

Back head resting: the bird tilts its neck towards its back, positioning the head between the wings with the beak tucked beneath scapulars. Eyes remain closed (Fig. 3J).

Bipedal resting: body erect and supported with both legs on the substrate, relaxed neck, closed wings and lowered tail. Lateral head and gular-fluttering movements may be present (Fig. 3K).

Unipedal resting: similar to bipedal resting, but the body rests with one leg on the substrate, while the other is retracted near the abdomen (Fig. 3L).

Gular-fluttering: the bird remains with its beak half open and vibrates its gular region. This behavior is prevalent during bipedal resting but can be performed during other behaviors. It is common on hot days (Fig. $3 \mathrm{M})$.

Neck lowering: the bird lowers its neck vertically towards the substrate (Fig. 3N).

Head lowering: similar to neck lowering, but the bird lowers only its head vertically toward the substrate (Fig. 3O).

Beak opening: the bird opens its beak quickly then closes it, as in a yawn. Variation: with its head lowered, the bird opens its beak slowly, accompanied by lateral movements of the head (Fig. 3P).

Neck shrinking: the bird shrinks its neck close to the body, forming an "s" (Fig. 3Q).

Wing leg stretching: the bird may or may not tilt its body slightly forward, then stretch its wing, followed by the tarsus on the same side of the body (Fig. 3R).

\section{Ingestion/excretion}

These behaviors are related to feeding and hydration activities (Fig. 4).

Foraging: the bird plunges in the water in search for fish by impelling the anterior part of the body, first submerging the head, then the trunk and, finally, the tail. Upon returning to the surface, only the neck and part of the back are exposed. Foraging can be carried out individually or in groups, and usually takes place on the lakeshore. During group foraging, individuals move in rows, forming a barrier to facilitate fish catching (Fig. $4 A)$.

Eating: The bird feeds when it emerges after diving during foraging, bringing a fish in its beak. It swings its head sideways to arrange the fish into a cranial position in the beak, then tilts the head and neck back and swallows the prey. It may drink water after feeding (Fig. 4B).

Drinking: the bird tilts its body under the water, lowers its neck and places its head inside the water (Fig. 4C). It picks up some water with its beak and vertically raises its head to swallow, with the beak half open (Fig. 4D).

Defecating: the body is slightly inclined forward, the feathers close to the cloaca become erect, the tail is lifted and stool is expelled (Fig. 4E).

\section{Locomotion}

These are behaviors related to changes in location, unrelated to feeding (Fig. 5).

Water moving: body in the water with exposed neck, tail and back. The bird slowly moves in the water by leg movements, without diving (Fig. 5A).

Open wings water moving: body in a position similar to water moving, but with wings open, high and close to the bird's head as it moves in the water. This behavior precedes flight (Fig. 5B).
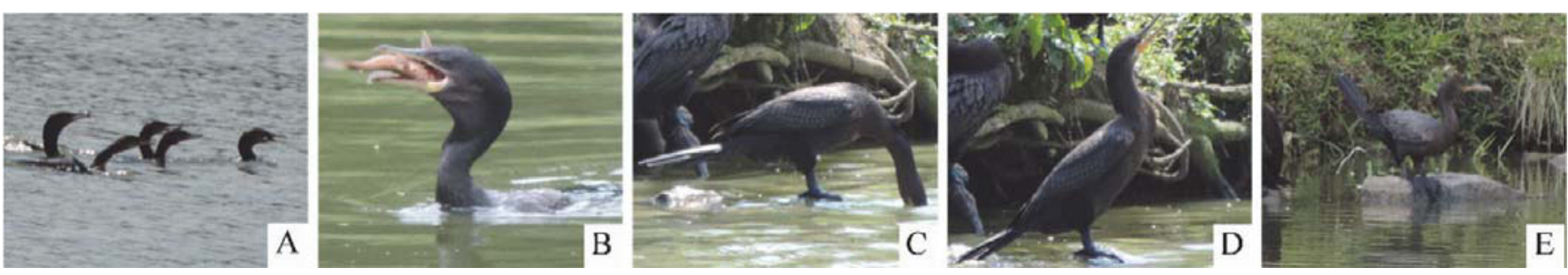

Figure 4. Behavioral conducts of Nannopterum brasilianus in the ingestion/excretion category: (A) Foraging, (B) Eating, (C, D) Drinking, (E) Defecating. 

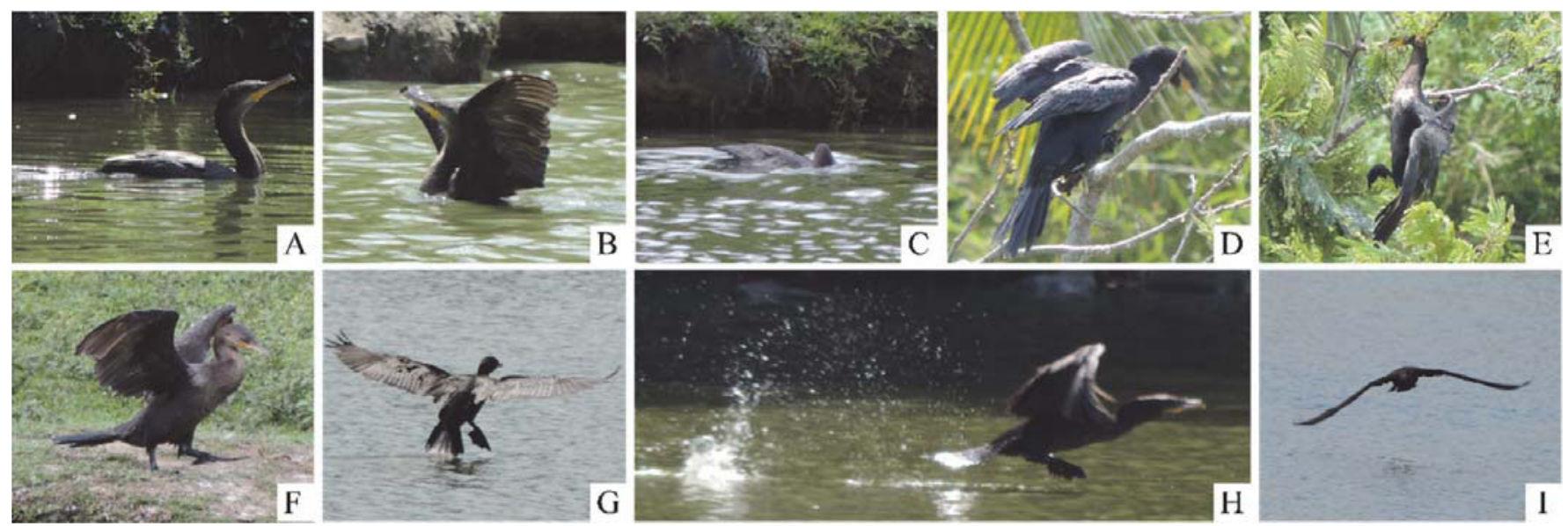

Figure 5. Behavioral conducts of Nannopterum brasilianus in the locomotion category: (A) Water moving, (B) Open wings water moving, (C) Head dive water moving, (D) Tree branch moving, (E) Falling, (F) Ground moving, (G) Water landing, (H) Water takeoff, (I) Flying.

Head dive water moving: body in a position similar to water moving, however, the bird repeatedly plunges its head and part of the neck underwater while moving in the water. This can be followed by head shaking when the head emerges (Fig. 5C).

Tree branch moving: the bird moves laterally on a branch with its body tilted forward and wings slightly open and slightly raised, moving one leg at a time in the target direction. It can rotate the body $180^{\circ}$ to change position and perform short jumps to move between nearby branches (Fig. 5D).

Falling: when the bird lands or moves on a branch in trees, it can become unbalanced and fall onto the substrate (the lake, in the case of the present study). To try to remain on the branch, it supports its head or body parts on the branch, with wings and tail open, but this does not usually prevent the fall (Fig. 5E).

Ground moving: the bird moves with one leg at a time in the target direction with its body slightly inclined forward, with wings semi-open or closed and raised tail, leaning the body towards the leg that supports it on the ground. The bird can rotate its body $180^{\circ}$ to change position (Fig. 5F).

Water landing: body tilted, wings open and raised, tarsi extended forward and tail open and lowered. The bird flies toward the water, flaps its wings and slides its legs into the water surface, with the tarsi being the first part of the body to come into contact with water. When sliding, the bird slows down, until the abdomen touches the water, after which the wings close immediately (Fig. 5G).

Water takeoff: with the body in the open wings water moving position, the bird flaps its wings and remains with the tail and tarsi in the water. Simultaneously, it moves its legs against the water surface, pushing its body out of the water until flight takes place (Fig. $5 \mathrm{H}$ ).

Flying: head, neck, trunk, and tail stretched and aligned horizontally, tarsi extended close to the body and tail open. The bird performs a beaten flight and can glide for a few seconds (Fig. 5I).

\section{Play}

These behaviors are related to the search and movement of inanimate objects with the beak (Fig. 6).

Single playing: happens on the ground, branches or water. On the ground, the bird grabs an inanimate object (branch, leaf or root) with its beak and swings it with its head in lateral movements until the object falls. It then picks up the same object and repeats the movement. On branches, the bird moves its head towards branches with leaves and tries to pull them out with its beak in rapid movements. In water, the bird catches an inanimate object with its beak and moves in the water with it and can swing its head laterally (Fig. 6A).

Group playing: when an individual carries an inanimate object in its beak, another bird approaches, vocalizes and tries to take the object with its beak (Fig. 6B). This second individual can pick it up from one end and both then pull on it, like on a tug of war. Other individuals can vocalize and perform a wing-waving display while approaching the bird with the object. In this display, the bird slightly tilts its body forward, the tail is open and raised, and the wings beat slightly. This can be accompanied by vocalization (Fig. 6C).

Ground searching: the bird tilts its body, lowers its neck towards the ground and, with its beak, looks for dry branches or leaves among the vegetation to play with. The bird may walk on the ground or remain in the same place (Fig. 6D).

\section{Agonistic behavior}

These are behaviors related to aggressive intra- and interspecific activities (Fig. 6). 

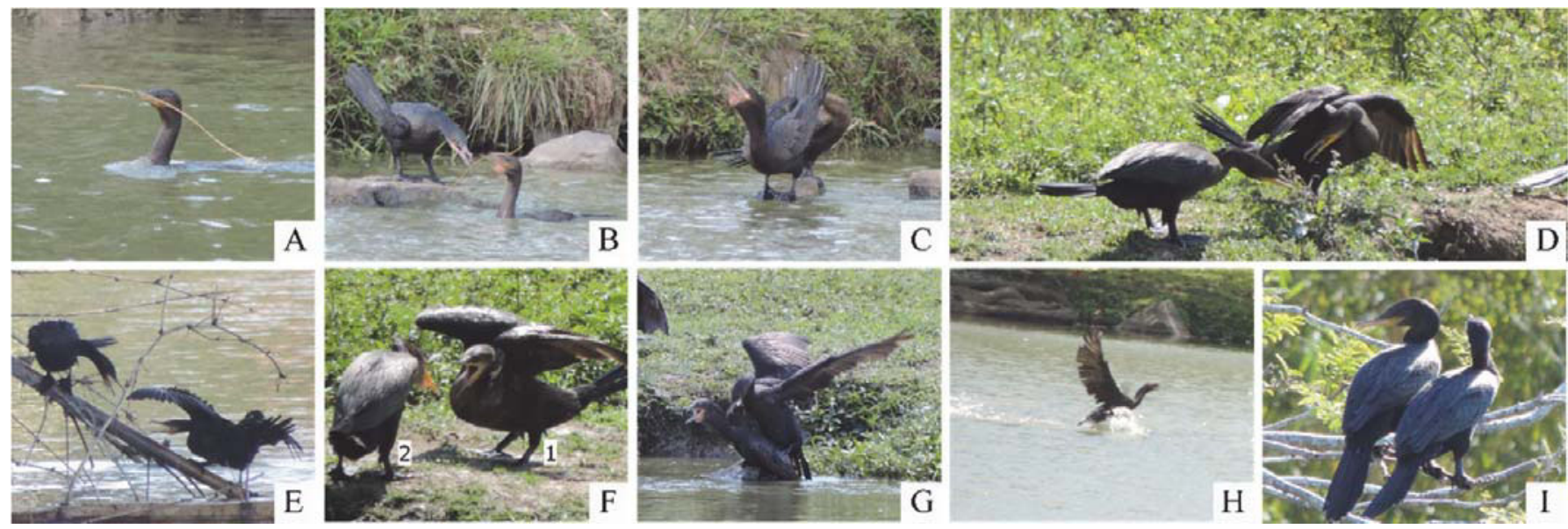

Figure 6. Behavioral conducts of Nannopterum brasilianus in the play and agonistic behavior categories: (A) Single playing, (B) Group playing, (C) Group playing - wing-waving display, (D) Ground searching, (E) Fighting, (F) Ground chasing, (G) Spot stealing, (H) Escaping, (I) Threat searching.

Fighting: body tilted, with wings open or closed. The bird stretches and moves its neck horizontally towards its opponent, and may peck it, preferably on the head or neck. The gular bag expands and the bird vocalizes (Fig. $6 \mathrm{E})$.

Ground chasing: the bird pursues the escaping opponent in a rapid ground displacement during fighting on the ground. The opponent (2) can either face the first individual (1) or continue to run (Fig. 6F).

Spot stealing: when resting on the substrate, another individual approaches and begins a fight. If the first individual does not change location, it climbs on the back of the opponent, flaps its wings, vocalizes and pecks the opponent on the neck and head (Fig. 6G). The attacked bird vocalizes and expands its gular bag. In most cases, it loses its balance and leaves the area, while the attacker occupies the free spot. The attacking bird may also give up stealing the spot and look for another resting place.

Escaping: displacement of the bird on the ground, branch, air or water, away from an intra- or interspecific threat. When escaping by ground, branch, and water, the bird moves short distances ( 1 to $2 \mathrm{~m}$ ), usually during intraspecific agonistic interactions, such as fighting or spot stealing. Regarding air movement, the bird flies at greater distances $(>2 \mathrm{~m})$, preferably during interspecific interactions, such as the approach of people or dogs. When it escapes through the air in areas near water, it propels its body through tarsi movement on the water surface, similar to water takeoff (Fig. $6 \mathrm{H}$ ).

Threat searching: the bird moves its head horizontally in the direction of possible threats (Fig. 6I). The body can move laterally.

Vocalization: occurs mainly during agonistic and play interactions. The bird opens its beak, expands its gular bag and vocalizes repeatedly with the proximity of another individual (oak, oak, oak ...). Variation: small hoarse (oak) during resting or foraging.

\section{DISCUSSION}

Lake Açu represents a valuable food, rest and overnight area for Neotropic Cormorants in urban surroundings. The resident population displayed seasonal variations during this monitoring, with greater abundance during the dry season. A similar pattern was reported for the nearby Guanabara Bay, southeastern Brazil (Alves et al. 2011). However, the opposite was recorded in wetlands in the south and north of Brazil (Branco 2002, Barquete et al. 2008, Silva et al. 2014). These variations may be related to migration between feeding and breeding sites during the year, which may differ locally (Sick 1997). Although adults displaying breeding plumage were found, no reproduction activities were observed. The population decreases during the rainy season correspond to migration to reproductive sites, usually islands, such as the Tijucas Islands (Alfavaca and Pontuda) in Rio Janeiro (Alves et al. 2011).

Neotropic Cormorant, as well as others cormorants, spend most of their daylight time in maintenance activities (King et al. 1995, Gwiazda 2000, Branco et al. 2009). The ethogram raised herein lists behaviors commonly found in Phalacrocoracidae family (e.g., Bartholomew et al. 1968, Oliveira \& Costa 2003, Nelson 2005). However, some behaviors seem to have different roles in Neotropic Cormorant. One of the most common behaviors of the family, wing spreading, is absent in several species belonging to the blue-eyed shag complex (Bernstein \& Maxson 1982), but was frequent in Neotropic Cormorant. The purpose of such behavior is controversial and may include thermoregulation (Clark-Jr. 1969), plumage drying (White et al. 2008) or intraspecific display of foraging success (Jones 1978). At Lake Açu, this behavior was carried out with wet plumage, followed or not by feeding and associated with behaviors to remove excess water, indicating a primary plumage drying purpose.

Behaviors associated with reproduction in other 
cormorants were recorded in non-reproductive situations among young individuals, indicating possible alternative purposes. The wing-waving display performed during group playing is a male advertising carried out during courtship to attract females or claim possession of the nest (van Tets 1965, Childress \& Bennun 2002). However, it can also be used in the defense of rest perches in Phalacrocorax carbo (Galván 2004). In the observed context, its function would relate to the claim of the inanimate object acquired by another individual. Spot stealing, the posture assumed by one individual when climbing on the back of another and pecking its neck, refers to mating behavior (Berry 1976). In addition, playing behaviors, such as looking for and manipulating leaves and branches, are similar to collecting material for the nest. Such behaviors among young individuals may favor the learning and practice of innate responses, facilitating communication between adults (Sazima 2008).

In conclusion, this study provides important information about the natural history of Neotropic Cormorant and can be used as a starting point for further ethological studies on the species.

\section{ACKNOWLEDGEMENTS}

We thank anonymous reviewers for helping to improve the manuscript and the National Council of Technological and Scientific Development (Conselho Nacional de Desenvolvimento Cientifico e Tecnológico - CNPq), for the scholarship awarded to T.L. da Silva during the accomplishment of this work.

\section{REFERENCES}

Alarcón P.A.E., Macchi P.J., Trejo A. \& Alonso M.F. 2012. Diet of the Neotropical Cormorant (Phalacrocorax brasilianus) in a Patagonian freshwater environment invaded by exotic fish. Waterbirds 35: 149-153.

Altmann J. 1974. Observational study of behavior: sampling methods. Behaviour 49: 227-267.

Alvares C.A., Stape J.L., Sentelhas P.C., Gonçalves J.L.M. \& Sparovek G. 2013. Köppen's climate classification map for Brazil. Meteorologische Zeitschrift 22: 711-728.

Alves V.S., Soares A.B.A., Couto G.S. \& Draghi J. 2011. Padrão de ocorrência e distribuição de Biguás Phalacrocorax brasilianus na Baía de Guanabara, Rio de Janeiro, Brasil. Revista Brasileira de Ornitologia 19: 469-477.

Barquete V., Vooren C.M. \& Bugoni L. 2008. Seasonal abundance of the Neotropic Cormorant Phalacrocorax brasilianus at Lagoa dos Patos Estuary, southern Brazil. Hornero 23: 15-22.

Bartholomew G.A., Lasiewski R.C. \& Crawford-Jr. E.C. 1968. Patterns of panting and gular flutter in cormorants, pelicans, owls, and doves. Condor 70: 31-34.

Bernstein N.P. \& Maxson S.J. 1982. Absence of wing-spreading behaviour in the Antarctic Blue-eyed Shag (Phalacrocorax atriceps bransfieldensis). Auk 99: 588-589.

Berry H.H. 1976. Physiological and behavioural ecology of the Cape
Cormorant Phalacrocorax capensis - Part 1. Madoqua 9: 5-30.

Bó N.A. 1956. Observaciones morfológicas y etológicas sobre el Biguá. Hornero 10: 147-157.

Branco J.O. 2002. Flutuações sazonais na abundância de Phalacrocorax brasilianus (Gmelin) no estuário do Saco da Fazenda, Itajaí, Santa Catarina, Brasil. Revista Brasileira de Zoologia 19: 1057-1062.

Branco J.O., Evangelista C.L., Lunardon-Branco M.J., AzevedoJúnior S.M. \& Larrazábal M.E. 2009. Atividade diária de Phalacrocorax brasilianus (Aves, Phalacrocoracidae), na região do Saco da Fazenda, Itajaí, SC, Brasil. Ornithologia 3: 73-82.

Casaux R., Ramón A., Tartara M.A., Borrell V. \& Gonc R. 2012. Diet of breeding Neotropic Cormorants at the Carrileufu River, Patagonia: is there any impact on recreational fish resources? Ardeola 59: 279-289.

Childress R.B. \& Bennun L.A. 2002. Sexual character intensity and its relationship to breeding timing, fecundity and mate choice in the Great Cormorant Phalacrocorax carbo lucidus. Journal of Avian Biology 33: 23-30.

Chiquieri A., Soler M.F., Cassano M.L., Braz M.M. \& Castro O. 1995. Vestibular. Rumos 10: 7-28.

Clark-Jr. G.A. 1969. Spread-wing postures in Pelecaniformes, Ciconiiformes, and Falconiformes. Auk 86: 136-139.

Cook T.R. \& Leblanc G. 2007. Why is wing-spreading behaviour absent in Blue-eyed Shags? Animal Behaviour 74: 649-652.

D'Angelo G.B. \& Sazima I. 2013. Commensal association of piscivorous birds with foraging otters in southeastern Brazil, and a comparison with such a relationship of piscivorous birds with cormorants. Journal of Natural History 48: 241-249.

Espinoza-Rodríguez N., Carrasquero J., Turris-Morales K., DelgadoOrtega G. \& Barrios-Garrido H. 2015. Asociaciones entre aves marinas y Sotalia guianensis en el sur del Golfo de Venezuela. Caldasia 37: 309-318.

Ferreira I., Ventura P.E.C. \& Luz H.R. 2010. Aves no campus da Universidade Federal Rural do Rio de Janeiro. Rio de Janeiro: Edur.

Galván I. 2004. Age-related spatial segregation of Great Cormorants in a roost. Waterbirds 27: 377-381.

Gheler-Costa C., Comin F.H., Gilli L.C. \& Verdade L.M. 2018. Foraging behavior of Brazilian Cormorant, Nannopterum brasilianus (Suliformes: Phalacrocoracidae). Zoologia 35: e14664.

Gokula V. 2011. An ethogram of Spot-billed Pelican (Pelecanus philippensis). Chinese Birds 2: 183-192.

Gwiazda R. 2000. Numbers of non-breeding cormorants and their time budget activity at eutrophic, sub-mountain reservoir in southern Poland. Cormorant Research Group Bulletin 4: 26-28.

Hammer Ø., Harper D.A.T. \& Ryan P.D. 2001. PAST: Paleontological Statistics Software Package for Education and Data Analysis. Palaeontologia Electronica 4: 9.

Jones P.J. 1978. A possible function of "wing-drying" posture in the Reed Cormorant Phalacrocorax africanus. Ibis 120: 540-542.

Kennedy M. \& Spencer H.G. 2014. Classification of the Cormorants of the world. Molecular Phylogenetics and Evolution 79: 249-257.

Kennedy M., Spencer H.G. \& Gray R.D. 1996. Hop, step and gape: do the social displays of the Pelecaniformes reflect phylogeny? Animal Behaviour 51: 273-291.

King D.T., Glahn J.F. \& Andrews K.J. 1995. Daily activity budgets and movements of winter roosting Double-crested Cormorants determined by biotelemetry in the delta region of Mississippi. Colonial Waterbirds 18: 152-157.

Nelson J.B. 2005. Pelicans, cormorants, and their relatives: the Pelecaniformes. New York: Oxford University Press.

Oliveira T.C.G. \& Costa L.C.M. 2003. Frequencies of the motion patterns in the maintenance and agonistic activities of the Phalacrocorax brasilianus in the marine and river environments in the state of Paraná, Brazil. Cormorant Research Group Bulletin 5: 45-49.

Prestes N.P. 2000. Descrição e análise quantitativa do etograma de Amazona pretrei em cativeiro. Ararajuba 8: 25-42. 
Quintana F., Yorio P., Lisnizer N., Gatto A. \& Soria G. 2004. Diving behavior and foraging areas of the Neotropic Cormorant at a marine colony in Patagonia, Argentina. Wilson Bulletin 116: 83-88.

Sakamoto K.Q., Sato K., Ishizuka M., Watanuki Y., Takahashi A., Daunt F. \& Wanless S. 2009. Can ethograms be automatically generated using body acceleration data from free-ranging birds? PLoS ONE 4: e5379.

Santos M.C.O., Oshima J.E.F., Pacifico E.S. \& Silva E. 2010. Feeding associations between Guiana Dolphins, Sotalia guianensis (van Bénèden, 1864) and seabirds in the Lagamar Estuary, Brazil. Brazilian Journal of Biology 70: 9-17.

Sazima I. 2008. Playful birds: cormorants and herons play with objects and practice their skills. Biota Neotropica 8: 259-264.

Schleidt W.M., Yakalis G., Donnelly M. \& McGarry J. 1984. A proposal for a standard ethogram, exemplified by an ethogram of the Bluebreasted Quail (Coturnix chinensis). Zeitschrift für Tierpsychologie 64: 193-220.
Sick H. 1997. Ornitologia brasileira. Rio de Janeiro: Nova Fronteira. Sigrist T. 2009. Guia de campo Avis Brasilis: avifauna brasileira. São Paulo: Avis Brasilis.

Silva E.F., Naif R.H., Barata F.D.B., Santos-Jr. L.S., França P.F. \& Campos C.E.C. 2014. Abundância sazonal de Phalacrocorax brasilianus (Gmelin, 1789) (Aves, Phalacrocoracidae) na porção norte da Bacia Amazônica, Macapá, Amapá, Brasil. Biota Amazônia 4: 64-67.

van Tets G.F. 1965. A comparative study of some social communication patterns in the Pelecaniformes. Ornithological Monographs 2: 1-88.

White C.R., Martin G.R. \& Butler P.J. 2008. Wing-spreading, wingdrying and food-warming in Great Cormorants Phalacrocorax carbo. Journal of Avian Biology 39: 576-578.

Yamamoto M.E. \& Volpato G.L. 2011. Comportamento animal. Natal: Editora da UFRN.

Associate Editor: Cristiano S. Azevedo. 